\title{
Discussion on the Artistic Conception of Once More to the Lake
}

\author{
Guiying Kong \\ Wuzhou University \\ International Exchange College \\ Wuzhou, China 543002
}

\begin{abstract}
Artistic conception is the product of thinking, it is blended of the scenes and feelings, nihility and reality, which has the aesthetic characteristics of boundless recall. In Once More to the Lake, White combined content conception and passion conception for the readers and with the help of delicate descriptions to the scenes today and the past memories, nostalgia and characters conversion. He changed the real scenes into imagine and created an artistic conception that the words were over and the idea was infinity so as to achieve the enlightenment of the more meanings of the scenes and image that time was endless and life changed forever.
\end{abstract}

Keywords-Once More to the Lake; artistic conception; scenes; feeling

\section{INTERPRETATION OF ARTISTIC CONCEPTION}

The beautiful essays can bring people the great enjoyment of beauty, and the elegant essays also need the author to create their own artistic conception. The artistic conception is the artistic life of essays, its success or failure is related to the value of essays aesthetics. Specifically, artistic conception is the product of thinking, it refers to a kind of artistic state harmonized and produced by the author's subjective thinking and objective scenery, it is a product mixed together with the heart of thinking activity, objective scenery and scenes, it is a combination of virtual and actual things like the unity of art combined by the outside image and meaning, having the characteristics of aesthetic perception of endless aftertastes. Artistic conception is also the artistic crystallization of the author's sentiment, which is the starting point of artistic creation and is also the starting point for readers to appreciate the essay. With built the artistic conception by the author, the readers can gallop on reconstructing the image of heaven and earth, they can see farther and deeper to get the essays of the enlightenment, edification and aesthetic enjoyment [1]. Therefore, as a kind of image of literature art, artistic

The paper is

1. Major project of Wuzhou university-level scientific research in 2016: "The Study on Artistic Conception and Figures of Speech of Once More to the Lake", project number: 2016B011.

2. Phase result of the key research base on humanities \& social sciences in Guangxi universities - The Research Center of Folk Literature in Xijiang River, (project number: Guangxi Educational Scientific Research [2014] 12)

3. Funded by "Youth Backbone Teachers' Training Program" of Wuzhou University. conception is not purely and singly referring to a particular scene, object or affection, but a mixture of literature created by subjective and objective factors of the overall atmosphere of beauty [2]. Artistic conception that the author creates can be divided into three successive levels: content conception, passion conception and artistic conception. In most cases, the essay has its scenery. The content conception which is a scenic object of affection is the most elementary. The passion conception which can express author's feeling directly is the second melt by the symbol and affection of the scenery and the objects. The artistic conception is the highest state which expresses the author's inner cognition, philosophy and essence of life [3].

\section{ONCE MORE TO THE LAKE}

Elwyn Brooks White (1899-1985) was the greatest essayist in the United States in the 20th century, his writing was simple and fluent, his scenic description was exquisite, and he was good at using the scenes to express his sincere feelings. Once More to the Lake was one of his most celebrated essays. In it, E.B White revisited the lake in the woods in Maine where his father used to take him to in his childhood. Under White's pen, very ordinary scenery of the remote lake became peaceful, full of wit and humor, which easily had the readers' heart to be charmed by its romance but without losing sagacity, grace and restraint but not lacking of thinking. That the essay's delicacy was that White blended nature, emotion, character, human nature, art and other beauties into the scenes, memories, illusions to build the artistic conception, at last, the artistic conception would make the readers feel that although scenes were still beautiful, but time was gone, the continuation of generations and inheritance was inevitable. Next, we would analyze and appreciate how White creates this artistic conception one by one.

\section{THE CREATION OF THE CONTENT CONCEPTION}

White's affection to the lake could date back to his childhood, more than 30 years ago. In the first paragraph of Once More to the Lake, White explained the background to the lake in the woods in Maine. At that time, his father would take him to the lake for the month of every August. In order to relive the memorable time and to comfort his missing, White also took his own children, and a couple of bass hooks and a spinner, to revisit old haunts. In the second paragraph, 
on the way to the lake, White began to wonder whether the scenery of the lake had changed. Whether the holy spot--the coves and streams, the hills that the sun set behind, or the camps and the paths behind the camps, all of them have aroused White to make endless memories and imagination. The grooves have lead White's mind back to the places of the landscape of the past, the memories of picturesque sceneries would also make the readers to think back everywhere together with White: coves, streams, hills, camps, paths. In fact, these pictures like poems are very ordinary, but in White's mind, the picture was so real, it has become a part of his childhood. What White remembered clearest was the early mornings, the lake was cool and motionless, the bedroom smelled of the lumber, he quietly got up, dressed softly, sneaked out, started out in the canoe, closed along the shore in the long shadows of the pines, White remembered being very careful never to rub his paddle against the gunwale for fear of disturbing the stillness of the cathedral. Now, decades had past, White still remembered how careful he was at that time. It could be seen that White and his father lived beside the lake on vocation was beautiful and eternal. his memory to the picturesque scenes was also real. It was the first time that White used his soothing tone, careful ink to describe intertwined scenes of the reality and memory which implied that the present scenes were the same as the past, scenery was still sweet, here, what he did was setting the stage for the next rendering of artistic conception.

\section{THE CREATION OF THE PASSION CONCEPTION OF "THERE HAD BEEN No YeARs"}

The most valuable essence in the essay was that White used the sentence- - "There had been no years" three times to create the nostalgic feeling. Each time, when White saw the lake's scenery, he would like to place his own nostalgic feelings on the immediate thoughts from his eyes to the past scenery in his childhood. After contrast between the present and past scenery, White would felt that the scenes were still in the eyes, but the years has changed. This detailed were:

In the fifth paragraph, when White went fishing with his son, he saw that the same damp moss was still wet in the bait can, the dragonfly was still hovered on the tip of his rod, the scenes reminded him of the past that his father took him to fish, they were the same as before, so, White signed with emotion that "everything was as it always had been, that the years were a mirage and there had been no years ",. When White saw the small waves, the rowboat, the ribs, the floorboards, the freshwater leavings, the dead helgramite, the wisps of moss, the rusty discarded fishhook, the dried blood were also the same as before, White touched again that "There had been no years between the ducking of this dragonfly and the other one - the one that was part of memory". In the sixth paragraph, After White caught two bass, they wanted to get back for a swim before lunch, the lake was exactly where they had left it, and he seemed to find that the utterly enchanted sea had not stirred for a few hours at all like the same scene he left as he was a boy. The

\footnotetext{
${ }^{1}$ The examples in this article are selected from "Advanced English I" Edited by College of Foreign Languages of Naikai University and published by Naikai University Press, Unit 3 Once More to the Lake.
}

sticks and twigs undulated in clusters on the lake bottom, the track of the mussel was plain, A school of small minnows swam by, so clear and sharp in the sunlight.......When White was feeling the real beautiful nature, Some campers were in swimming, so the water seemed to feel thin and clear and insubstantial, and the scene seemed not to be true, the time seemed disappeared. White could not help saying again: "There had been no years".

Apparently, White embodied his feelings in "There had been no years", the graceful and beautiful were the scenes of the content conception that White described, and the lapse of time became the passion conception that White expressed his nostalgic feelings. The artistic conception created by the outside description of real scenes and the inside feelings of the train of thought would make the readers not only deepen the finer impression, but more cherish the memory of the past life and enjoy the current life, at the same time, the readers still could feel the continuation and inheritance of life. So, when the readers appreciate the lake of the picturesque sceneries, according to the artistic conception which White created for them, they could open their train of thought again to imagine the scenes and the objects of the lake for getting the enlightenment and edification, simultaneously, they would think the theme positively about the ephemeral life and existing eternity.

\section{THE CREATION OF THE ARTISTIC CONCEPTION OF CHARACTER TRANSFORMATION}

In the fourth paragraph, White laid in bed, smelling the bedroom, hearing his boy sneaked quietly out and went off along the shore in a boat. White began to sustain the illusion that his boy was him, he was his father. This sensation in this setting persisted so much strong, kept cropping up all the time they were there, which made White feel as if he was living a dual existence. White would be in the middle of some simple act, picking up a bait box or laying down a table fork, or saying something, but, suddenly White felt he was not him but his father who was saying or doing something which gave him a creepy sensation. Here, White increased his power to describe his inside feeling to his illusion about the constantly transforming characters among father, him and his son, thus got the spiritual perception of his heart. The lake's scenery was as the same before, it aroused White (as a father) to recall the past time from time to time and to produce his illusion constantly which always made White feel the time insanity, it seemed that his son was him and he was his father who was talking or doing things. This sensation of constantly transformation always lingered and haunted in his mind, as if White was put into a dual identity, his illusion of the reality and the past was described so accurately, the moments of the superposition between "I" was in middle-aged and "I" was in childhood would have relived the inevitable feelings of revisiting and missing scenery. Thus, apparently, White described the lake sceneries (objects), but he paid more attention in deed to the feeling's change in his inner thoughts (scenes). The scenes intertwined constantly by the charging pictures or not in his mind, with the help of this writing skill of the space-time inversion technique, White prepared for further creating the highest state of artistic conception. 
In the eleventh paragraph, White described several scenes by the lake, he lay down in the accumulated heat of the little bedrooms in the evening, the breeze stirred imperceptibly outside and the smell of the swamp drift in through the rusty screens, sleep came easily. In the morning, the squirrel was on the roof, tapping, White was lying in bed, remembering the small steamboat ran on the moonlight sails, how sweet were the mandolins sound of the older boys and the songs of the girls on the water. All the things in the store were in the same place, all was just as it had always been, except there was more Coca Cola...... White and his son explored the streams quietly, the turtles slid off the sunny logs and dug their way into the soft bottom. They lay on the town wharf and fed worms to the tame bass. White began to have such illusion that everywhere we went I had trouble making out which was I, the one walking at my side, the one walking in my pants. In these various but the same scenes of today and the past, White was in the dual role of identity again (his son, himself and his father), so he was in such a trance "the one (the character of his son) walking at my side" and "the one (the character of his father) walking in my pants." The artistic conception of the role dislocation created by White expressed his real feeling happening before his eyes (transferred among his son, himself and his father from time to time), which gave White a deep thinking: he was a son before but a father now who was only the living entity connecting the past and the future. During to the nostalgia for the past life and the enjoyment of the real life, White both felt the life of inheritance and continuity.

In the 13th paragraph, White's son wanted to swimming with others, As the past generation, White had no any thoughts of going in, he just watched his son Languidly, a new generation, winced slightly, pulled up around his vitals the small, soggy, icy garment, White was thoughtful. As his son buckled the swollen belt, White wrote that his groin suddenly felt the chill of death, those descriptions stimulated the topic of the artistic conception: many things could remain unchanged in the world, but the years went by, "I (White)" has already felt that the death was coming. Whether White narrated that he and his son went fishing or his father with him went fishing, their identity never changed (they were father and son), what has changed was the characters (White and his son, White and his father). The roles of father, himself and son were overlapped, transferred and dislocation in space-time which made the slight sadness of White flow out, the readers were touched naturally (passion conception), meanwhile, from which White conveyed his philosophy of life to nature and life, existence and death: with time moving on, years was relentless, the metabolism of the life (the continuation of generations) was eternal (artistic conception). Thus insight of White gave out from inside to outside was so frank and honest that could make the readers have greatly discerning and apprehending feelings that the words were over and the idea was infinity so as to achieve his enlightenment, edification and aesthetic feeling

\section{CONCLUSION}

Undoubtedly, White was the great master of creating the artistic conception, Once More to the Lake was exactly such a best representative essay. Using a simple, soothing, kind, elegant language, White gave a detailed description to the scenes of the lake, contrasted its present and its past, and it created the artistic conception of the remote, placidity and illusion for the readers. This writing method seemed to just describe a forest lake scenes, seemed to just describe the past time, also seemed to recall his childhood, but also seemed to taste the present time, but, suddenly, things were not those things, man was not that man, the years has always moved forward. White was so smart to combine his feelings with the subsistent objects, scenes to create a remote, quiet, soothing, nostalgic passion conception. The blending of them urged White to think the philosophical questions about the nature and the life, the existence and the death (artistic conception). Indeed, White's writing style was excellent, the scenes' description was very delicate. He was adept in associating the present objects, scenes with the past memories to show inner emotional thoughts, and then to build a rich connotation of artistic conception, to deepen the life and the eternal theme, which could make the readers appreciate the beautiful essay, simultaneously, also inspire their endless reverie.

\section{REFERENCES}

[1] Ling Huangxin. The characteristic of artistic conception creation [J]. Journal of Nanjing Normal University (Social Science Edition), 1985(4):27-31.

[2] Li Jian. The creation of Bixing Thinking and Artistic Worlds [J]. Journal of Peking University (Philosophy and Social Sciences), 2003(3): 83-89.

[3] Chen Liangyun. The Theory of Chinese Poetics [M]. Beijing: China Social Sciences Publishing House, 1998:241. 